Kumawula, Vol. 4, No.1, April 2021, Hal 74 - 78

DOI: https://doi.org/10.24198/kumawula.v4i1.31211

ISSN 2620-844X (online)

Tersedia online di http://jurnal.unpad.ac.id/kumawula/index

\title{
PENINGKATAN KREATIVITAS MASYARAKAT MELALUI PENGOLAHAN JAGUNG DI DESA KUMPULREJO KECAMATAN PARENGAN KABUPATEN TUBAN
}

\author{
Dyah Setyaningrum $^{*}$, Ita Yunira Septiani ${ }^{2}$ \\ ${ }^{1}$ Fakultas Sains dan Teknik, Universitas Bojonegoro \\ ${ }^{2}$ Fakultas Ekonomi, Universitas Bojonegoro \\ *Korespondensi: dyahds@gmail.com
}

\begin{abstract}
This community service program was motivated by the abundance of dry season agricultural products in Kumpulrejo Village, Parengan Sub-district, Tuban District, with the main commodity being corn. The main problem and obstacle faced by the farmers in the Kumpulrejo Village area is the lack of diversification of processed maize products with high selling power. This condition is due to a lack of knowledge and information about the nutritional value of maize, the appearance of food products from corn that are less attractive, and the assumption that corn is only consumed by people with low economies. A solution that can be done is to make processed corn into creative and innovative food products, for example, milk and cheese corn pudding (jasuke). The service was carried out by means of direct socialization and product demonstrations. The main targets were mothers and young women. This activity went well and was successful. This was evidenced by the enthusiasm of the residents in participating in the activities and the presence of residents who continue this new business opportunity. The results obtained from this community service program were the creation of public understanding of the importance of entrepreneurship, improving community skills in processing various food products by paying attention to GMP (Good Manufacturing Practices), creating business opportunities for the community, and increasing community income.
\end{abstract}

Keywords: corn; jasuke; entepreneurship; diversification

\begin{abstract}
ABSTRAK
Program pengabdian masyarakat ini dilatarbelakangi dengan melimpahnya hasil pertanian musim kemarau yang ada di Desa Kumpulrejo, Kecamatan Parengan, Kabupaten Tuban. Dengan komoditas utamanya adalah jagung. Permasalahan dan kendala utama yang dihadapi para petani jagung di daerah Desa Kumpulrejo adalah belum adanya diversifikasi produk olahan jagung yang berdaya jual tinggi. Kondisi ini dikarenakan masih rendahnya pengetahuan dan minimnya informasi tentang nilai gizi jagung, tampilan produk pangan dari jagung yang kurang menarik, dan adanya anggapan bahwa jagung hanya dikonsumsi oleh masyarakat berekonomi lemah. Solusi yang dapat dilakukan adalah dengan membuat olahan jagung menjadi produk makanan yang kreatif dan inovatif, misalnya puding jagung susu keju (jasuke). Pengabdian dilakukan dengan dengan cara sosialisasi dan demo pembuatan produk secara langsung. Target utamanya adalah ibu - ibu dan remaja putri. Kegiatan ini berjalan dengan lancar dan sukses. Hal ini dibuktikan dengan antusias warga dalam mengikuti kegiatan serta adanya warga yang melanjutkan peluang bisnis baru ini. Hasil yang diperoleh dari program pengabdian masyarakat ini adalah terciptanya pemahaman masyarakat akan pentingnya berwirausaha, meningkatkan keterampilan masyarakat dalam mengolah berbagai produk makanan dengan memperhatikan GMP (Good Manufacturing Practices), menciptakan peluang usaha bagi masyarakat, serta meningkatkan pendapatan masyarakat
\end{abstract}

Kata Kunci: jagung; jasuke; wirausaha; diversifikasi 


\section{PENDAHULUAN}

Desa Kumpulrejo termasuk dalam wilayah Kecamatan Parengan, Kabupaten Tuban dengan luas wilayah $\pm 753 \mathrm{Ha}$. Tanah daerah ini bermineral dan berstruktur lembab; pasir berwarna orange; kandungan air tinggi; dan didominasi lahan pertanian. Desa yang terdiri dari 2 Dusun, 5 RW dan 25 RT ini dihuni oleh mayoritas warga yang berprofesi sebagai petani. Komoditas utama yang ditanam di Desa Kumpulrejo adalah padi dan jagung yang ditanam secara bergantian. Pada musim kemarau, komoditas utama yang ditanam adalah jagung. Berdasarkan data BPS (2018) bahwa di Kecamatan Parengan luas lahan panen jagung adalah \pm 6.496 ha dengan produksi jagung sebanyak \pm 39.443 ton.

Di Indonesia, jagung merupakan bahan pangan pokok yang kedua setelah beras. Jagung merupakan sumber karbohidrat dan juga protein, terutama bagi masyarakat yang sedang diet (Widowati, 2012). Kandungan protein jagung cukup tinggi, yaitu $8-12 \%$, serat kasar $0,8-2,5 \%$, serta karbohidrat $68-73 \%$ (Ullah dkk., 2010). Menurut Wulandari \& Batoro (2016), jagung adalah tanaman rerumputan tropis yang sangat adaptif terhadap perubahan iklim dan memiliki masa hidup 70 - 210 hari. Tanaman dengan nama latin Zea mays ini, dapat tumbuh hingga ketinggian 3 meter. Tidak seperti tanaman biji-bijian lain, tanaman jagung merupakan satu-satunya tanaman yang bunga jantan dan betinanya terpisah (Belfield, 2008).

Dari potensi daerah dan juga keunggulan jagung tersebut, maka perlu adanya pengolahan jagung menjadi berbagai macam produk olahan, sehingga meningkatkan nilai ekonomi dan nilai guna jagung sebagai bahan pangan non beras. Mukti dkk. (2018) menyatakan bahwa pendidikan kewirausahaan masih sangat dibutuhkan oleh petani di Indonesia, sehingga memiliki ketertarikan untuk mencoba sesuatu yang baru dalam kegiatan usahanya serta tentunya dapat memberikan tambahan pendapatan masyarakat.
Secara umum, permasalahan dan kendala utama yang dihadapi para petani jagung di daerah Desa Kumpulrejo adalah belum adanya upaya dan pengembangan usaha diversifikasi produk olahan jagung yang berdaya jual tinggi. Kondisi ini dikarenakan masih rendahnya pengetahuan dan kurangnya informasi tentang nilai gizi jagung, tampilan produk pangan dari jagung yang kurang menarik, dan adanya anggapan bahwa jagung hanya dikonsumsi oleh masyarakat berekonomi lemah. Alternatif yang dapat dilakukan adalah dengan membuat olahan jagung menjadi produk makanan yang kreatif dan inovatif melalui kegiatan pemberdayaan masyarakat Desa Kumpulrejo. Pemberdayaan masyarakat merupakan upaya yang dilakukan oleh masyarakat, dengan atau tanpa dukungan dari pihak luar, untuk memperbaiki kehidupannya yang berbasis kepada daya mereka sendiri, melalui upaya optimasi daya serta peningkatan posisi tawar yang dimiliki, dengan perkataan lain, pemberdayaan harus menempatkan kekuatan masyarakat sebagai modal utama serta menghindari "rekayasa" pihak luar yang seringkali mematikan kemandirian masyarakat setempat (Solihah, 2020).

Tujuan dari kegiatan ini adalah untuk meningkatkan kreativitas ekonomi masyarakat, terutama yang terdampak Covid-19 di Desa Kumpulrejo, Parengan, Tuban dalam menghasilkan olahan tanaaman jagung menjadi produk yang bernilai ekonomis. Selain itu, melalui kegiatan ini diharapkan juga menambah adanya minat masyarakat untuk berwirausaha sehingga dapat meningkatkan pendapatan keluarga.

\section{METODE}

Pelaksanaan KKN PPM ini dilaksanakan pada bulan Agustus 2020 dengan denah lokasi kegiatan di Desa Kumpulrejo, Kecamatan Parengan, Kabupaten Tuban (Gambar 1). Peserta kegiatan ini adalah mahasiswa Universitas Bojonegoro dan masyarakat desa. KKN PPM tahun 2020 dilaksanakan dengan mematuhi protokol kesehatan sesuai standar 
WHO. Sehingga sosialisasi dilaksanakan secara berulang dan bergiliran dengan jumlah peserta yang dibatasi.

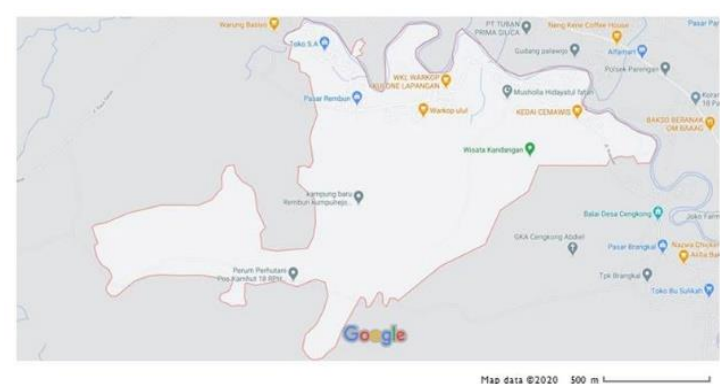

\section{Gambar 1. Denah Lokasi KKN PPM di Desa Kumpulrejo, Parengan, Tuban}

Program KKN PPM ini target utamanya adalah ibu - ibu dan remaja putri di Desa Kumpulrejo dan dilaksanakan dengan tiga tahap, yaitu persiapan, pelaksanaan, serta evaluasi (Gambar 2).

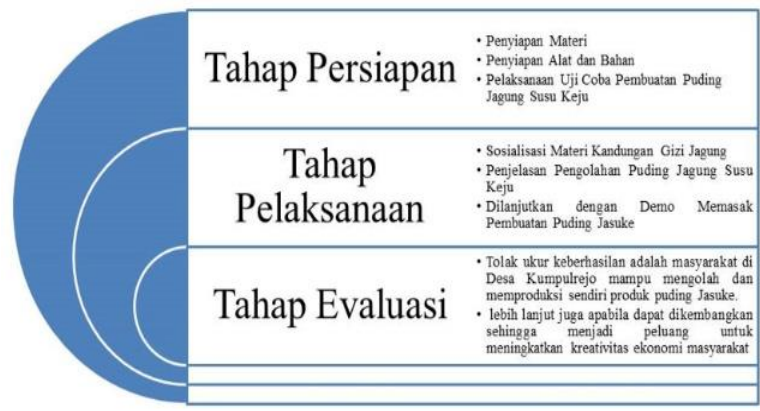

\section{Gambar 2. Metode Pelaksanaan KKN- PPM di Desa Kumpulrejo, Parengan, Tuban}

\section{HASIL DAN PEMBAHASAN}

\section{Penyuluhan dan Diskusi}

Penyuluhan dilakukan di rumah warga dengan mematuhi protokol kesehatan sehingga sosialisasi dilakukan secara berulang dan jumlah peserta dibatasi sesuai kondisi wilayah lokasi (Gambar 3). Adapun materi yang disampaikan adalah mengenai kandungan gizi jagung sebagai bahan utama dan juga cara pengolahan puding jagung susu keju (Jasuke). Dalam hal ini, poin utamanya adalah pemahaman terhadap pentingnya pengolahan hasil jagung dibandingkan menjual langsung ke pasar. Tentu saja hal ini akan berpengaruh pada nilai jual yang akan semakin tinggi. Hasil dari kegiatan ini adalah bertambahnya pemahaman, keterampilan, kreativitas, dan ide inovatif masyarakat dalam mengolah hasil pertanian utamanya jagung.
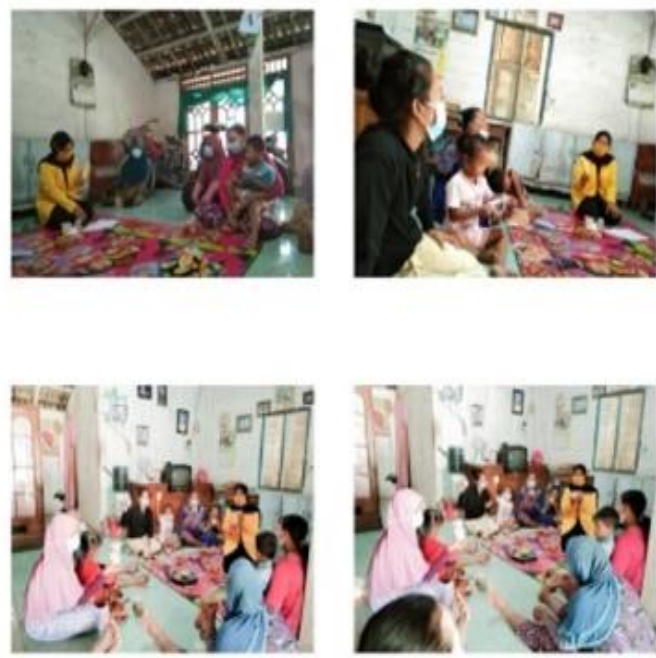

Gambar 3. Penyuluhan dan Diskusi di Rumah Warga dengan Memenuhi Protokol Kesehatan

Tantangan dalam pengembangan pengolahan dan pemasaran produk adalah perubahan lingkungan ekonomi, tuntutan pasar terkait efisiensi usaha, dinamika permintaan, dan perubahan preferensi (selera) terhadap informasi nutrisi serta jaminan keamanan produk pertanian (Yanti, dkk, 2019). Pengembangan kreativitas masyarakat ini umumnya kurang memperhatikan aspek distribusi dan konsumsi. Sehingga melalui kegiatan pemberdayaan masyarakat ini diharapkan para pelaku wirausaha nantinya dapat mempertimbangkannya juga. Oleh sebab itu, pengolahan hasil palawija menjadi produk olahan yang baru, memiliki rasa yang sesuai dengan preferensi masyarakat, serta harga yang terjangkau, diharapkan dapat berpotensi untuk dikembangkan bagi masyarakat pedesaan seperti di Desa Kumpulrejo, Parengan, Tuban.

\section{Demonstrasi dan Pelatihan}

Antusias masyarakat cukup tinggi pada saat diadakan demo memasak puding jasuke. Hal ini mengindikasikan bahwa pelatihan berjalan dengan sukses. Saat demonstrasi dan pelatihan juga diberikan pengarahan terkait penerapan GMP (Good Manufacturing Practices). 
Menurut Setyaningrum \& Maghfiroh (2020), bahwa proses standar GMP digunakan untuk menentukan mutu hasil produksi terkait dengan keamanan atau keselamatan konsumen. Proses utama yang paling ditekankan dalam proses ini adalah agar tidak terjadi kontaminasi terhadap produk selama proses produksi (Gambar 4).

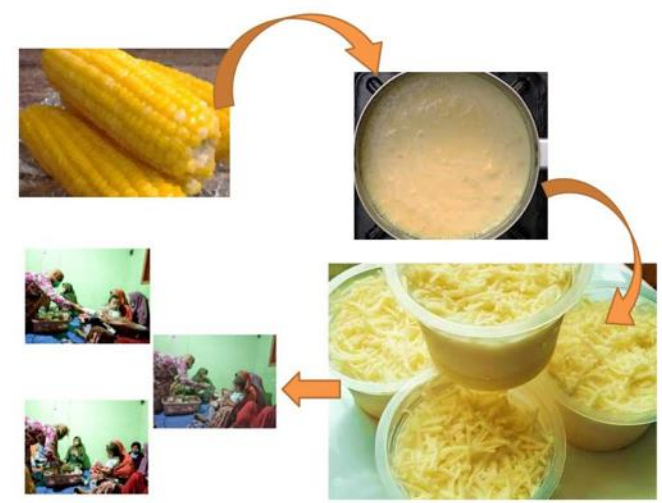

\section{Gambar 4. Demo Memasak dan Pelatihan Proses Pengolahan Puding Jasuke}

Dari hasil kegiatan ini, ada beberapa warga yang tertarik untuk melanjutkan dan mengembangkan olahan produk puding jasuke ini. Namun, penjualannya masih di daerah sekitar Desa Kumpulrejo dengan dititipkan di warung dan penjaja sayur. Disebabkan untuk pemasaran secara global atau keluar daerah, suatu produk pangan harus memiliki izin dari BPOM dan telah memiliki label halal dari MUI. Maka dari itu, diperlukan kegiatan berkelanjutan dalam menjadikan produk ini sebagai peluang bisnis yang lebih menjanjikan bagi masyarakat. Sehingga diperlukan suatu pendampingan yang bersifat berkelanjutan baik dari Universitas Bojonegoro maupun pemerintah desa dan dari Dinas terkait.

\section{SIMPULAN}

Hasil yang diperoleh dari program pengabdian masyarakat ini adalah terciptanya pemahaman masyarakat akan pentingnya berwirausaha, peningkatan keterampilan masyarakat dalam mengolah berbagai produk makanan, menciptakan peluang usaha bagi masyarakat, serta peningkatan pendapatan masyarakat. Diharapkan agar kegiatan ini bersifat berkelanjutan sehingga menjadikan produk olahan jagung menjadi bisnis yang menjanjikan bagi masyarakat khusunya Desa Kumpulrejo, Kecamatan Parengan, Kabupaten Tuban. Pendampingan secara terus menerus dari pihak Universitas Bojonegoro, pemerintah desa, maupun dinas terkait perlu dilakukan untuk meningkatkan keberhasilan dan pengembangan usaha dalam jangka panjang. Perluasan pasar untuk aspek distribusi produk juga dibutuhkan dalam pengembangan usaha ini.

\section{DAFTAR PUSTAKA}

Belfield, S. (2008). Field Crop Manual: A Guide to Upland Production in Cambodia Maize. New South Wales: NSW Department of Primary Industries.

BPS. (2018, November 13). Retrieved 2020, from Tuban BPS: https://tubankab.bps.go.id/statictable/20 18/11/13/300/luas-panen-jagungkedelai-kacang-tanah-kacang-hijau-ubikayu-ubi-jalar-menurut-kecamatan-dikabupaten-tuban-hektar-2017-.html

Mukti, G. W., Sadeli, A. H., \& Kusno, K. (2018). Penguatan Kapasitas Kewirausahaan Petani Muda Hortikultura Skala Kecil di Kecamatan Parongpong, Kabupaten Bandung Barat. Kumawula, 50-61.

Setyaningrum, D., \& Maghfiroh, A. M. (2020). Pendampingan Pengurusan Izin Edar BPOM Produk Jamu Gendong Desa Ngablak, Kecamatan Dander, Kabupaten Bojonegoro. Jurnal Abdinus, 235-245.

Solihah, R. (2020). Pemberdayaan Masyarakat melalui Pemanfaatan Pekarangan sebagai Warung Hidup Keluarga di Desa KutaMandiri Kecamatan Tanjungsari. Kumawula, 204-215.

Ullah, I., Ali, M., \& Farooqi, A. (2010). Chemical and Nutritional Properties of Some Maize (Zea mays L.) Varieties Grown in NWFP, Pakistan. Pakistan Journal of Nutrition, 1113-1117. 
Widowati, S. (2012). Keunggulan Jagung QPM (Quality Protein Maize) dan Potensi Pemanfaatannya dalam Meningkatkan Status Gizi. Pangan, 171-184.

Wulandari, F., \& Batoro, J. (2016). Etnobotani Jagung (Zea mays L.) Pada Mayarakat Lokal di Desa Pandansari Kecamatan Poncokusumo Kabupaten Malang. Jurnal Biotropika, 17-24.

Yanti, Y., Busniah, M., Syarif, Z., \& Pasaribu, I. S. (2019). Peningkatan Kreativitas Masyarakat melalui Usaha Produk Olahan Tanaman Palawija di Nagari Sungai Durian, Solok, Sumatera Barat . Agrokreatif, 58-63. 